University of Nebraska - Lincoln

DigitalCommons@University of Nebraska - Lincoln

Waterfowl Management Handbook

US Fish \& Wildlife Service

January 1991

\title{
13.4.18. Chufa Biology and Management
}

James R. Kelley Jr.

Gaylord Memorial Laboratory, The School of Natural Resources, University of Missouri-Columbia, Puxico, MO

Leigh $\mathrm{H}$. Fredrickson

Gaylord Memorial Laboratory, The School of Natural Resources, University of Missouri-Columbia, Puxico, MO

Follow this and additional works at: https://digitalcommons.unl.edu/icwdmwfm

Part of the Environmental Sciences Commons

Kelley, James R. Jr. and Fredrickson, Leigh H., "13.4.18. Chufa Biology and Management" (1991). Waterfowl Management Handbook. 34.

https://digitalcommons.unl.edu/icwdmwfm/34

This Article is brought to you for free and open access by the US Fish \& Wildlife Service at DigitalCommons@University of Nebraska - Lincoln. It has been accepted for inclusion in Waterfowl Management Handbook by an authorized administrator of DigitalCommons@University of Nebraska - Lincoln. 


\subsubsection{Chufa Biology and Management}

J ames R. Kelley, J r., and Leigh H. Fredrickson

Gaylord Memorial Laboratory

TheSchool of Natural Resources

University of Missouri-Col umbia

Puxico, MO 63960

\section{Introduction}

Chufa (Cyperus esculentus) is an emergent perennial sedge that is common in seasonally flooded wetlands. Although chufa is common in many States, it is most abundant in the Southeast, including the Mississippi alluvial valley (Fig. 1). Bel owground biomass of chufa, especially the tubers, serves as a valuable food source for waterfowl and cranes. Chufa tubers rank tenth among the most important waterfowl foods in the United States.

\section{Identification}

Other common names for chufa are yellow nutsedge, nutgrass, and ground almond. Plants are 8 inches to 3 feet tall and have 3-sided stems (Fig. 2). Leaves are bright green on emergence but become pale green as plants mature. Leaves are $0.2-0.4$ inches wide and ribbonlike. The main stem terminates in an inflorescence that has 3-9 leaflike bracts, 2-10 inches long, at its base. The inflorescence comprises 5-10 stalks with strongly flattened spikes that are up to 1.25 inches long and yellow or golden-brown. The seeds are 3-sided,

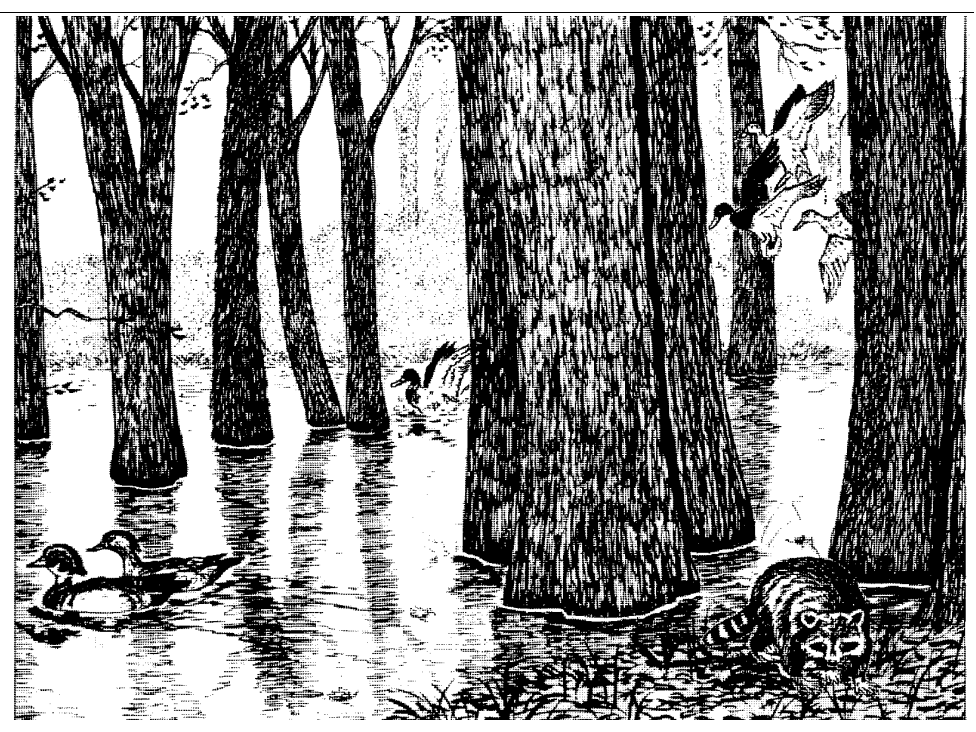

elliptical, rounded at the end, and 0.04-0.06 inches $(1.2-1.5 \mathrm{~mm})$ in length. Mature tubers are tan or black, sphere-shaped, and 0.2-0.4 inches long. Newly formed tubers are white.

\section{Nutritional Value}

Chufa tubers are an important, high-energy food for birds. The caloric density of tubers averages $4.26 \mathrm{kcal} / \mathrm{g}$. Approximately $45 \%$ of the fresh weight of tubers is water. The major components of the dry weight of tubers are carbohydrate (58\%), lipid (10\%), protein (7\%), and ash (3\%). The major fatty acid in tubers is oleic ( $61 \%$ of total fatty acids), while other fatty acids include linoleic (24\%), palmitic (12\%), and stearic (2\%).

\section{Life History}

\section{Reproduction and Growth}

Reproduction from seed is relatively unimportant. Seed production is variable and on some sites only a few or no seeds are produced, whereas heavy seed production occurs on other sites. Seeds often are inviable and seedlings produced from seed are usually weak. Sprouting from tubers is the primary mode of reproduction by chufa, and potential production from tubers is high. For example, in 1 year a single tuber in Minnesota produced 1,900 plants and 6,900 tubers. 


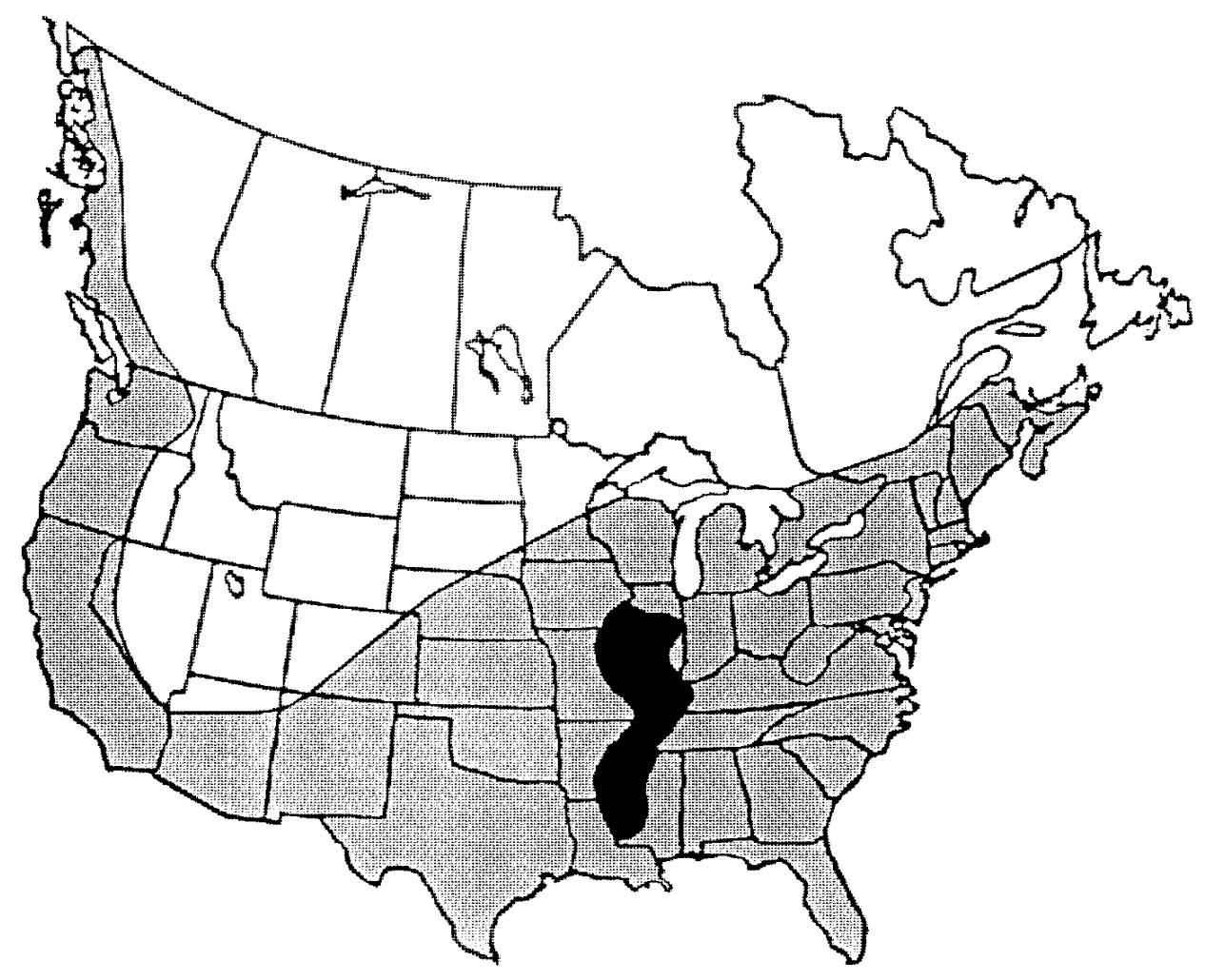

Fig. 1. Distribution of chufa in North America, showing principal range (l ight shaded areas) and areas of greatest abundance (dark shading).

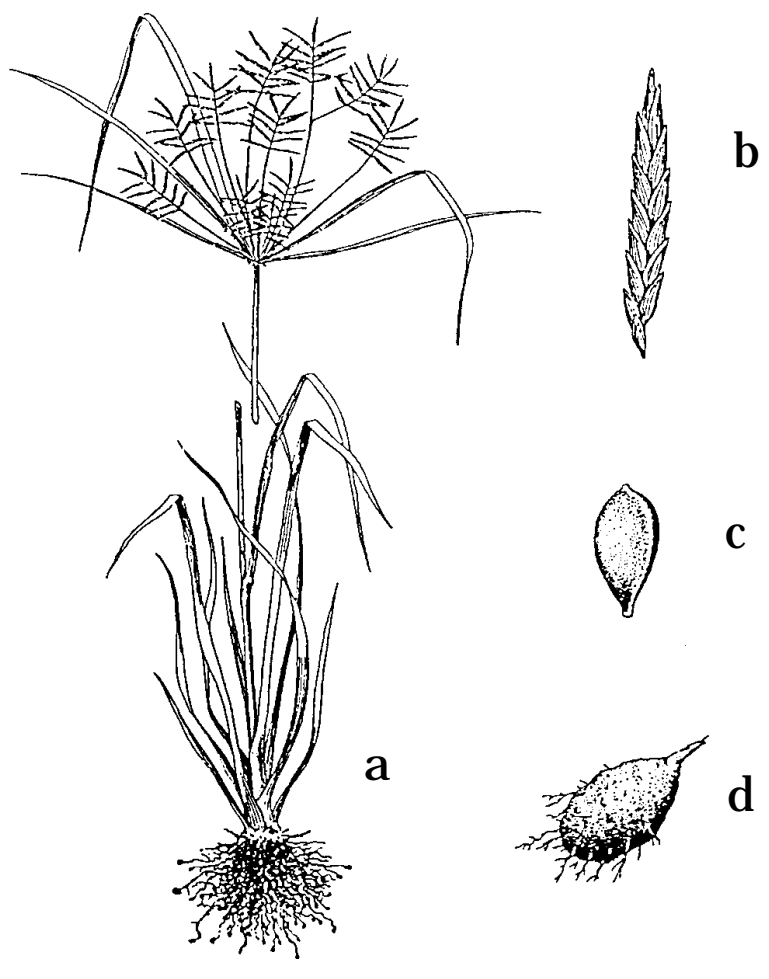

Fig. 2. I dentifying characteristics of chufa: a) entire plant, b) spikelet, c) seed, and d) tuber. 
Mature tubers have 5- 7 buds, located in the axils of scale leaves. In spring, two buds usually sprout and form rhizomes. Removal of sprouts from tubers induces additional buds to sprout. Elongating rhizomes are indeterminate, underground stems that terminate in a bud that either forms a new tuber or a basal bulb. Basal bulbs produce leaves that el ongate to form aerial shoots.

In wetland areas, the timing of shoot emergence is dependent on drawdown date. Removal of surface water stimulates sprouting of tubers, and shoots begin to emerge within a few days after surface water removal. Stem densities increase rapidly following drawdown, and peaks in aboveground biomass occur as soon as 40 days after drawdown (Fig. 3).

Production of new tubers occurs as soon as 18 days after drawdown. Tubers are formed throughout the growing season; however, most tuber devel opment occurs within the first month after shoot emergence. Belowground biomass production peaks approximately 1 month after aboveground biomass has reached its peak (Fig. 3). At the end of the growing season, $85 \%$ of bel owground biomass is composed of tubers. Tubers regularly survive winter conditions whereas aerial shoots, basal bulbs, and rhizomes rarely survive from one growing season to the next. Tubers can remain dormant for up to 3.5 years. Dormancy is broken by leaching of a growth inhibitor (abscisic acid) from tubers or by physical damage to tubers.

\section{Soil Requirements}

Chufa grows well in a variety of soil conditions: clay, clay loam, silty clay, loam, sandy gravel, and sand. Production is often greatest on silty clay soils and lowest in sand. Soils with $\mathrm{pH}$ values between 5.0 and 7.5 give the best production.

\section{Temperature}

The minimum temperature required for sprouting of tubers in the laboratory is $12^{\circ} \mathrm{C}$
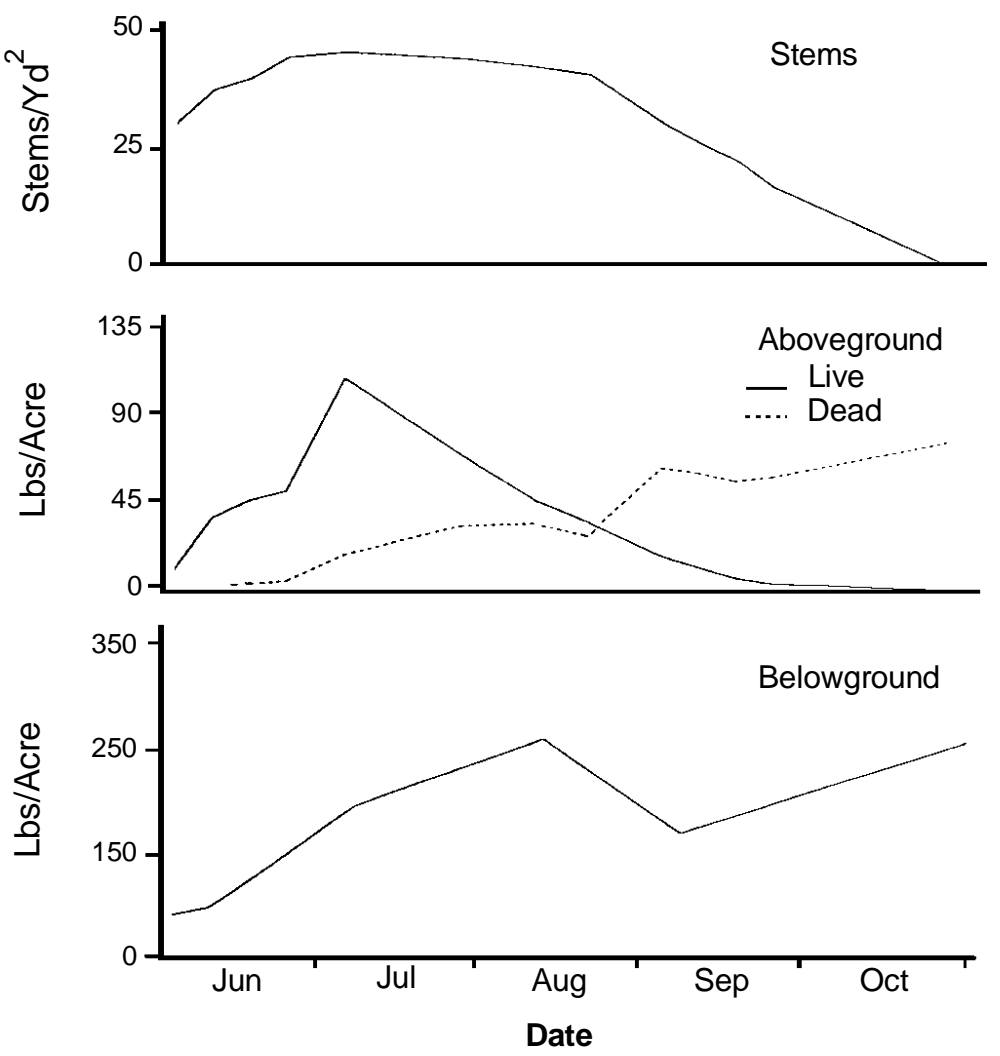

Fig. 3. Stem density (stems per square yard), live and dead aboveground biomass (pounds per acre), and total belowground biomass (pounds per acre) of chufa following a 27 May drawdown in southeast Missouri. 
$\left(54^{\circ} \mathrm{F}\right)$. Little is known about optimum temperature for sprouting in the field. Tubers can withstand winter soil temperatures of -7 to $-10^{\circ} \mathrm{C}$ (14 to $\left.19^{\circ} \mathrm{F}\right)$, but survival is greatest at temperatures above $-4^{\circ} \mathrm{C}\left(25^{\circ} \mathrm{F}\right)$.

\section{Moisture}

Chufa is adapted to seasonally flooded environments. Emergence begins as soil temperatures increase following exposure of soil surfaces during drawdown. Maximum tuber production occurs in soils that remain moist or when stands are irrigated. Chufa can withstand temporary flooding if the plants are not completely covered with water. Prol onged flooding during the growing season is not recommended. Drought conditions severely reduce tuber production and cause mortality.

\section{Light}

Chufa competes poorly with other plants because of its light requirements. As little as 30\% shade can reduce dry-matter production by $32 \%$. The quick emergence and rapid growth of chufa allows plants to mature and produce tubers before being subjected to shading by other plant species. The early senescence of chufa often makes it difficult to detect at the time of fall flooding because most of the aboveground parts have decomposed.

\section{Management Techniques}

\author{
Soil Manipulations
}

Because most wetland management schemes are directed toward seed production, little information is published concerning manipulations that enhance tuber production. If chufa is present in the seed or bud bank of a seasonally flooded site, some tuber production likely will occur in the absence of active manipulations, depending on the growing conditions and other factors, such as soil disturbance by feeding waterfowl. H owever, chufa production may be enhanced by proper soil disturbance (e.g., disking or plowing), which is often used to eliminate woody growth and undesirable perennials in managed wetlands. Shallow (2-4 inches) disking detaches many chufa tubers from parent plants, which causes tubers to sprout and develop as additional plants (Fig. 4). Following disking, many parent plants remain on the surface, reestablish themselves, and continue tuber production. Disking scarifies some of the dormant tubers and induces sprouting. Sites should be irrigated after disking to prevent desiccation of tubers and parent plants. If irrigation is not possible after disking and dry conditions prevail, tuber production will below because of poor growing conditions. However, the soil disturbance for chufa production is not wasted because the effects of disking carry over to the

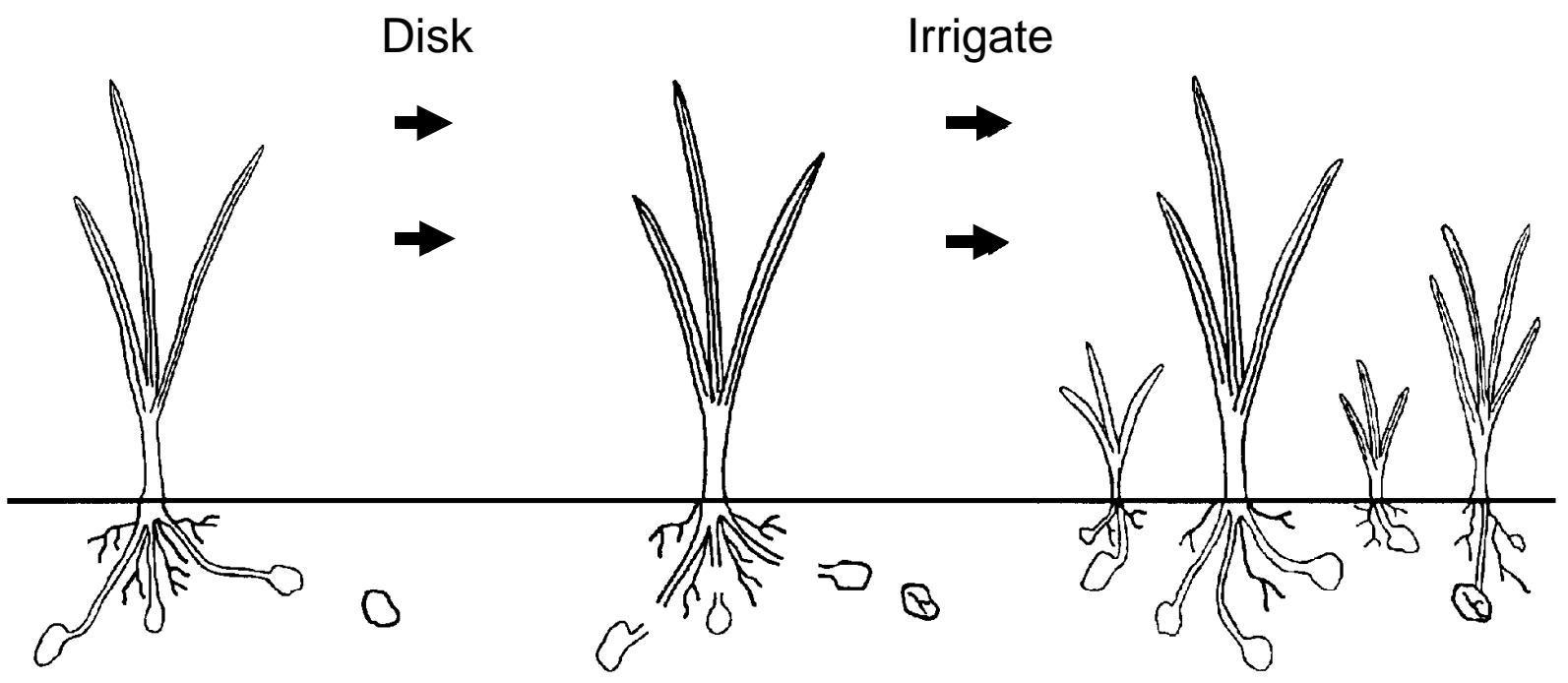

Fig. 4. Use of shallow disking and irrigation to stimulate additional sprouting of active and dormant chufa tubers to increase waterfowl food production. 
following year. Thus, chufa production may be enhanced in the next growing season. Shallow disking may not be feasible over entire management units if eradication of severe vegetation problems requires deep disking. In situations where there is a history of good chufa production, deep disking might be restricted to patches of undesirable vegetation. Sites lacking vegetation problems, or where undesirable vegetation is less dense, might be shallowly disked. Because deep disking buries many parent chufa plants and results in low tuber production, whereas shallow disking stimulates tuber production, each management scenario can be expected to result in major differences in chufa production (Fig. 5.; Table 1).

\section{Plantings}

Most planting of chufa occurs on upland areas in the Southeast for wild turkey (Meleagris gallopavo) food production. If chufa is desired on wetland sites that contain no natural growth, propagation can be initiated by broadcasting tubers. Chufa tubers are available from wholesale seed companies, which generally sell them in 100-pound bags. A slow, early- to midseason (1 March-15 J une) drawdown should be part of site preparation for planting. While sheet water is still present, tubers should be broadcast at the rate of 50 pounds per acre over sites lacking standing vegetation. Tubers will sprout when surface water recedes. Once established, additional plantings generally are not necessary. Grazing should be restricted when tubers are planted because cattle and hogs consume chufa tubers.

\section{Availability to Birds}

Waterfowl have unusual abilities to locate belowground tubers. By the time management units are flooded in fall, there is little evidence of aboveground parts. Nevertheless, waterfowl and cranes consistently locate and consume tubers. The availability of tubers for waterbirds is influenced by water depth. The majority of tubers are near the soil surface at a depth of $0-4$ inches (Table 2). Thus, optimal water depth for dabbler utilization of tubers is 2-8 inches. Disking tends to loosen soil sediments and makes foraging for tubers easier for birds. When birds forage intensively on sites with good tuber production, they cause soil disturbance that is as effective as shallow disking. During the subsequent growing season such sites have the potential for good tuber production.

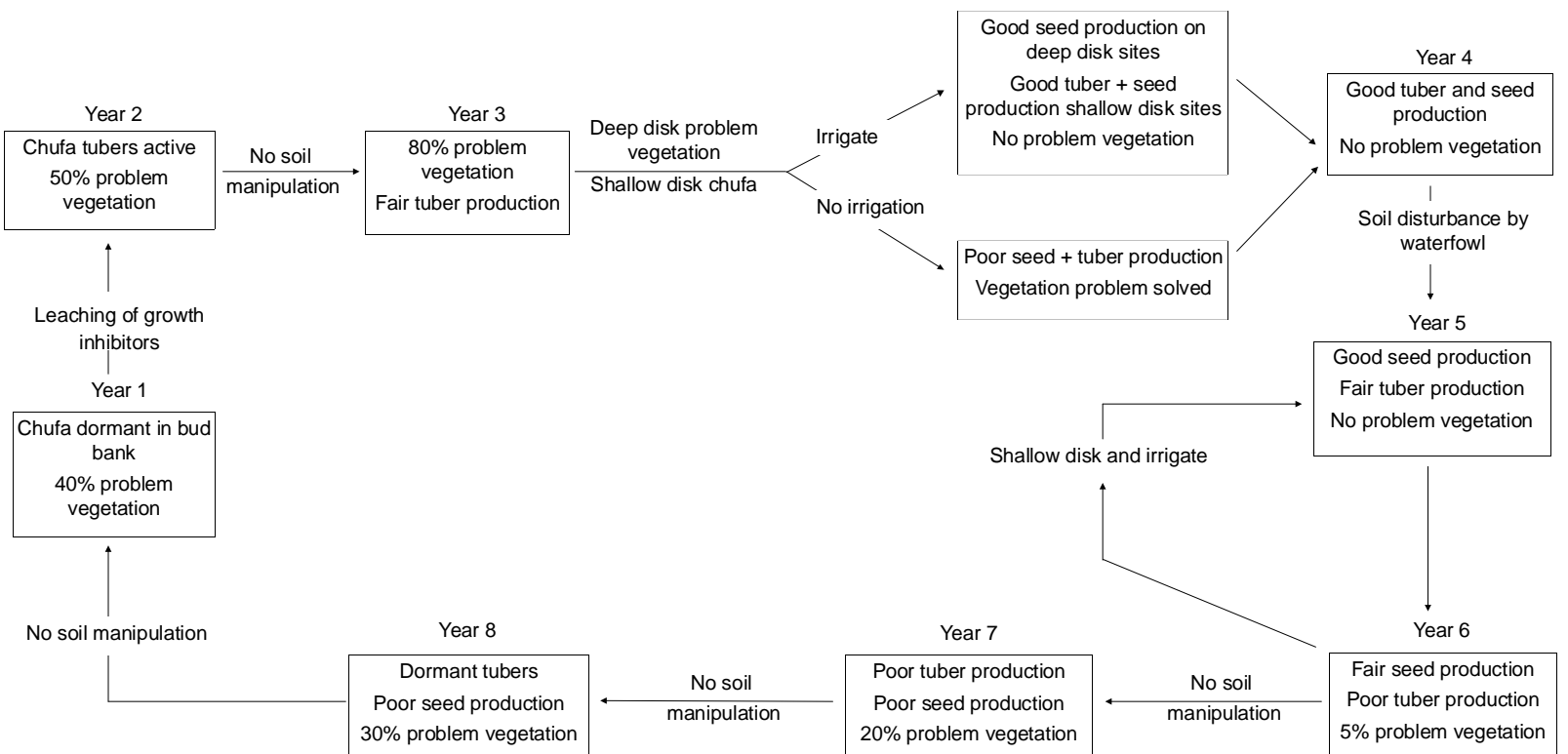

Fig. 5. L ong-term conditions and manipulations to enhance chufa tuber production in a seasonally flooded impoundment. The flow chart illustrates the effects of no soil disturbance and how disking influences chufa tuber production and the control of undesirable vegetation. Problem vegetation refers to undesirable woody species and robust non-seed-producing perennials. 
Table 1. Chufa (Cyperus esculentus) belowground production (pounds per acre) following implementation of six different management scenarios involving combinations of disking depth and irrigation.

\begin{tabular}{cccc}
\hline & \multicolumn{3}{c}{ Disking treatment } \\
$\begin{array}{c}\text { Irrigation after } \\
\text { disking }\end{array}$ & $\begin{array}{c}\text { No disk } \\
\text { Shallow }\end{array}$ & $\begin{array}{c}\text { Deep } \\
\text { (2 inches) }\end{array}$ & (6 inches) \\
No irrigation & 159 & 327 & 13 \\
\hline
\end{tabular}

Table 2. Depth distribution of chufa (Cyperus esculentus) tubers in the soil profile.

\begin{tabular}{lccc}
\hline & \multicolumn{3}{c}{ Depth (inches) } \\
\cline { 2 - 4 } & $\frac{0-2}{48}$ & $\frac{2-4}{43}$ & $\frac{4+}{9}$ \\
$\begin{array}{l}\text { Percent of tubers } \\
\text { Percent of dry }\end{array}$ & 25 & 62 & 13 \\
\hline
\end{tabular}

\section{Suggested Reading}

Fredrickson, L. H., and T. S. Taylor. 1982. Management of seasonally flooded impoundments for wildlife. U.S. Fish Wildl. Serv., Resour. Publ. 148. 29 pp.

Kelley, J . R., J r. 1990. Biomass production of chufa (Cyperus esculentus) in a seasonally flooded wetland. Wetlands 10:61-67.

Mitchell, W. A., and C. O. Martin. 1986. Chufa (Cyperus esculentus): Section 7.4.1, U. S. Army Corps of Engineers Wildllife Resources Management Manual, Technical Report EL-86-22. U.S. Army Corps Eng. Waterways Exp. Stn., Vicksburg, Miss.

Mulligan, G. A., and B. E. J unkins. 1976. The biology of Canadian weeds. 17. Cyperus esculentus L. Can. J . Plant Sci. 56:339-350.

Stoller, E. W., D. P. Nema, and V. M. Bhan. 1972. Yellow nutsedge tuber germination and seedling devel opment. Weed Sci . 20:93-97.

Wills, D. 1971. Chufa tuber production and its relationship to waterfowl management on Catahoula Lake, Louisiana. Proc. Annu. Conf. Southeast. Assoc. Game Fish Comm. 24:146-153.

Note: Use of trade names does not imply U.S. Government endorsement of commercial products.

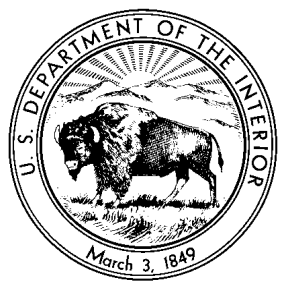

UNITED STATES DEPARTMENT OF THE INTERIOR

FISH AND WILDLIFE SERVICE

Fish and Wildlife Leaflet 13

Washington, D.C. $\bullet 1991$

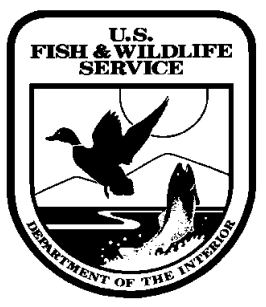

